\title{
Synthesis of Chromium(III) Oxide Nanoparticles by Electrochemical Method and Mukia Maderaspatana Plant Extract, Characterization, $\mathrm{KMnO}_{4}$ Decomposition and Antibacterial Study
}

\author{
Rakesh $^{1}$, S. Ananda1, Netkal M. Made Gowda ${ }^{2}$ \\ ${ }^{1}$ Department of Studies in Chemistry, University of Mysore, Mysore, India \\ ${ }^{2}$ Department of Chemistry, Western Illinois University, One University Circle, Macomb, USA \\ Email: rakesh_chemin@yahoo.com, snananda@yahoo.com,gn-made@wiu.edu
}

Received June 14, 2013; revised August 5, 2013; accepted September 2, 2013

Copyright $(\odot 2013$ Rakesh et al. This is an open access article distributed under the Creative Commons Attribution License, which permits unrestricted use, distribution, and reproduction in any medium, provided the original work is properly cited.

\begin{abstract}
Chromium oxide nanoparticles were synthesized by the reduction of potassium dichromate solution with Mukia Maderaspatana plant extract. In electrochemical methods, $\mathrm{Cr}_{2} \mathrm{O}_{3}$ nanoparticles were synthesized by two ways, using platinum (Pt) electrodes and $\mathrm{K}_{2} \mathrm{Cr}_{2} \mathrm{O}_{7}$ solution with $\mathrm{H}_{2} \mathrm{SO}_{4}$ as medium in the first case. And chromium doped platinum electrode $(\mathrm{Pt} / \mathrm{Cr})$ in presence of $\mathrm{NaHCO}_{3}$ solution in second case. The resulting $\mathrm{Cr}_{2} \mathrm{O}_{3}$ nanoparticles were characterized by X-ray diffraction (XRD), Scanning electron microscopy (SEM), UV-VIS absorption and Fourier-transform infrared (FTIR) spectroscopy. The enhancing influence of $\mathrm{Cr}_{2} \mathrm{O}_{3}$ nanoparticles as a catalyst for the decomposition of $\mathrm{KMnO}_{4}$ has been studied. The antibacterial effect of $\mathrm{Cr}_{2} \mathrm{O}_{3}$ nanoparticles against $E$. coli was investigated. These particles were shown to have an effective bactericide.
\end{abstract}

Keywords: Potassium Dichromate Solution; $\mathrm{Cr}_{2} \mathrm{O}_{3}$ Nanoparticles; Chromium Doped Platinum Electrode (Pt/Cr); E. coli

\section{Introduction}

The study of fine and ultrafine particles has received increasing interest due to new properties that material may show when the grain size is reduced [1]. During the past decades, considerable progress in the synthesis of nanoparticles has been achieved. Nanomaterials, particularly transition-metal oxides play an important role in many areas of chemistry, physics and material science [2]. In technological applications, metal oxides have traditionally been used in the fabrication of microelectronic circuits, sensors, piezoelectric devices, fuel cells, coatings for the passivation of surface against corrosion, and as catalyst [2]. In the emerging field of nanotechnology, a goal is to make nanostructures or nanoarrays with special properties with respect to those of bulk or single particles species. Metal oxides as nanoparticles can exhibit unique chemical properties due to their limited size and high density of corner or edge surface sites [2,3]. Among metal oxides, special attention has been focused on the formation and properties of chromia $\left(\mathrm{Cr}_{2} \mathrm{O}_{3}\right)$ which is important as heterogeneous catalyst [4], coating material, wear resistance [5,6], advanced colorant [7], pigment [8] and solar energy collector [9].

Various techniques for the synthesis of $\mathrm{Cr}_{2} \mathrm{O}_{3}$ nanoparticles such as hydrothermal [10], sol gel [11], combustion [12], precipitation-gelation [7], gel citrate [13], mechanochemical process [14], urea-assisted homogeneous precipitation [15], gas condensation [16], and microwave plasma have been developed [17]. Both chromium oxide and supported chromium have been used as catalyst in many reactions such as oxidation of toluene [18], ethane dehydrogenation [12], and methanol decomposition [3]. In this study, we have synthesized chromium(III) oxide nanoparticles by different methods and their catalytic effects on the $\mathrm{KMnO}_{4}$ decomposition and antibacterial activity have been reported here.

\section{Experimental}

Chromium oxide nanoparticles are synthesized by three different methods and the comparative study for the 
above synthesized nanoparticles is undertaken.

\subsection{Method 1 (Biological Method)}

Potassium dichromate from Rankem was used without further purification. Mukia Maderaspatana plants were collected from Hassan district and the edible part of the whole plant was shade dried and pulverized using a mechanical grinder. The powdered plant material (50 g) was extracted with methanol $(200 \mathrm{ml})$ by soxhlet apparatus for $24 \mathrm{hrs}$. The extract was evaporated using a rotaryvaccum evaporator at $40^{\circ} \mathrm{C}$ to provide dry extract. The extract was kept at $-20^{\circ} \mathrm{C}$ until use. The preliminary phytochemical analysis of the extract revealed the presence of various bioactive components, such as alkaloids, flavonoids, phenolics, aminoacids and glycosides [19]. An amount of $10.0 \mathrm{~g}$ of potassium dichromate was dissolved in $50 \mathrm{ml}$ distilled water and stirred for $10 \mathrm{~min}$. An orange colored solution was obtained.

Preparation of $\mathrm{Cr}_{2} \mathrm{O}_{3}$ nanoparticles:

In an experiment, $20 \mathrm{ml}$ of potassium dichromate solution was mixed with $20 \mathrm{ml}$ of plant extract in a beaker and stirred for 10 - $15 \mathrm{~min}$. The colour of the solution changed from orange to green indicating the formation of chromium(III) oxide nanoparticles. The solution was kept at room temp for evaporation of aqueous phase. The green solid product was dried in hot air oven at $65^{\circ} \mathrm{C}$ $70^{\circ} \mathrm{C}$ for an hour. The resulting solid was calcined at $650^{\circ} \mathrm{C}-700^{\circ} \mathrm{C}$ for $3 \mathrm{hrs}$. The addition of potassium dichromate solution to the plant extract containing mild reducing agents causes the reduction of orange dichromate(VI) ions to green chromium(III) ions. As an example, the reduction of $\mathrm{Cr}^{6+}$ to $\mathrm{Cr}^{3+}$ by reducing sugars resulting in the formation of $\mathrm{Cr}_{2} \mathrm{O}_{3}$ nanoparticles is shown below.

The chemical reaction takes place according to the following mechanism (Scheme 1)

$$
\begin{aligned}
& 3 \mathrm{RCHO}+\mathrm{Cr}_{2} \mathrm{O}_{7}^{2-}+8 \mathrm{H}^{+} \rightarrow \\
& 3 \mathrm{RCOOH}+2 \mathrm{Cr}^{3+}+4 \mathrm{H}_{2} \mathrm{O}
\end{aligned}
$$

Half equation for the reduction of dichromate(VI) ion is

$$
\mathrm{Cr}_{2} \mathrm{O}_{7}^{2-}+14 \mathrm{H}^{+}+6 \mathrm{e}^{-} \rightarrow 2 \mathrm{Cr}^{3+}+7 \mathrm{H}_{2} \mathrm{O}
$$

Combining that with the half equation for the oxidation of an aldehyde in aqueous condition

$$
\mathrm{RCHO}+\mathrm{H}_{2} \mathrm{O} \rightarrow \mathrm{RCOOH}+2 \mathrm{H}^{+}+2 \mathrm{e}^{-}
$$

The reduction of $\mathrm{Cr}^{6+}$ to $\mathrm{Cr}^{3+}$ plays a main role in this process and then $\mathrm{Cr}_{2} \mathrm{O}_{3}$ is generated.

$$
2 \mathrm{Cr}^{3+}+3 \mathrm{H}_{2} \mathrm{O} \rightarrow \mathrm{Cr}_{2} \mathrm{O}_{3}+6 \mathrm{H}^{+} \quad \text { (Scheme 1) }
$$

\subsection{Method 2 (Electrochemical Method in Presence of $\mathrm{K}_{2} \mathrm{Cr}_{2} \mathrm{O}_{7}$ and $\mathrm{H}_{2} \mathrm{SO}_{4}$ )}

Chromium oxide nanoparticles are synthesized electrochemically using platinum electrodes. A solution of potassium dichromate $(0.3 \mathrm{M})$ was prepared. The electrochemical cell consists of reaction chamber a voltage power supply and platinum electrodes. The experiment was performed with $20 \mathrm{ml}$ volume of potassium dichromate solution along with $5.0 \mathrm{ml}$ of conc. $\mathrm{H}_{2} \mathrm{SO}_{4}$ as a supporting medium. A positive voltage of $12 \mathrm{~V}$ was applied using battery eliminator (Neulite India) and current output of $70 \mathrm{~mA}-90 \mathrm{~mA}$. The experiment was run for $3 \mathrm{hrs}$ with continuous stirring. A change in colour from orange to dark green was observed. The above solution was allowed for the slow evaporation in a hot air oven at $100^{\circ} \mathrm{C}$ for $2 \mathrm{hrs}$. The dried solid which was obtained showed positive results for sulphate test. Further, the solid was calcined at $650^{\circ} \mathrm{C}-700^{\circ} \mathrm{C}$ for removal of moisture and sulfate as sulfur dioxide. The reduction equation is as shown in equation below:

$$
\begin{aligned}
& 2 \mathrm{~K}_{2} \mathrm{Cr}_{2} \mathrm{O}_{7}+8 \mathrm{H}_{2} \mathrm{SO}_{4} \rightarrow 2 \mathrm{~K}_{2} \mathrm{SO}_{4}+2 \mathrm{Cr}_{2}\left(\mathrm{SO}_{4}\right)_{3} \\
& +3 \mathrm{O}_{2}+8 \mathrm{H}_{2} \mathrm{O} \\
& \quad 4 \mathrm{Cr}_{2}\left(\mathrm{SO}_{4}\right)_{3} \rightarrow 4 \mathrm{Cr}_{2} \mathrm{O}_{3}+12 \mathrm{SO}_{2}+6 \mathrm{O}_{2}
\end{aligned}
$$

\subsection{Method 3 (Electrochemical Method in the Presence of $(\mathrm{Pt} / \mathrm{Cr})$ and $\left.\mathrm{NaHCO}_{3}\right)$}

In this method a thin film of chromium was deposited electrochemically on a platinum electrode $(\mathrm{Pt} / \mathrm{Cr})$ from chromium nitrate solution $(0.1 \mathrm{M})$. The preparation of $\mathrm{Cr}_{2} \mathrm{O}_{3}$ nanoparticles was carried in a reaction chamber containing $20 \mathrm{ml}$ of $\mathrm{NaHCO}_{3}$ solution. Voltage power supply of $12 \mathrm{~V}$, current of $30 \mathrm{~mA}$ and $\mathrm{Pt} / \mathrm{Cr}$ electrode as anode, Pt electrode as cathode were used. The experiment was run for $3 \mathrm{hrs}$ with continous stirring at constant temperature. The anodic dissolution of chromium to give $\mathrm{Cr}^{3+}$ ions due to electrolytic reaction, which are electrochemically reacted with aqueous $\mathrm{NaHCO}_{3}$ to form $\mathrm{Cr}^{3+}$ oxides/hydroxides, which is shown in Scheme 2. The synthesis takes place at the electrode-electrode interface or close to the electric double layer [20]. The product formed floats in the electrolyte solution the resulting gel was filtered [21], washed several times with distilled water till complete removal of unreacted $\mathrm{NaHCO}_{3}$ and dried at $100^{\circ} \mathrm{C}$ for dehydration and removal of hydroxides. The dried compound was calcined for $3 \mathrm{hrs}$ at $650^{\circ} \mathrm{C}-700^{\circ} \mathrm{C}$ in muffle furnance in order to decompose the hydroxides of chromium and to get chromium(III) oxide.

The Electrochemical reaction takes place according to the following mechanism: 


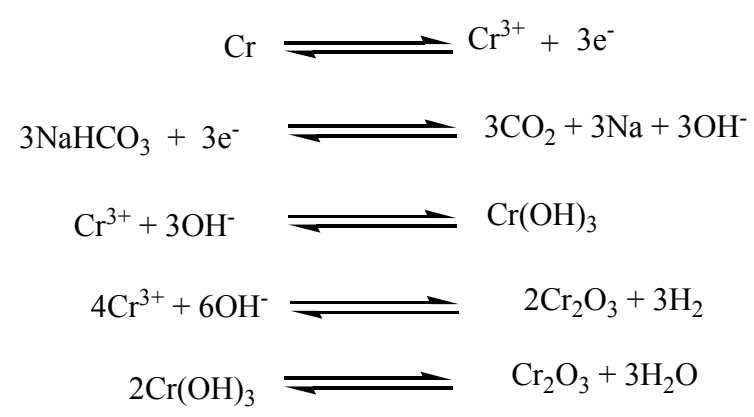

(Scheme 2)

\section{Results and Discussion}

Characterization of the chromium oxide nanoparticles was carried out by different techniques. UV-Visable spectra were measured using (ELICO SL171) model double beam spectrophotometer. FTIR spectra were recorded with Fourier-transform infrared instrument between $4000 \mathrm{~cm}^{-1}$ to $400 \mathrm{~cm}^{-1}$. The morphological properties of the $\mathrm{Cr}_{2} \mathrm{O}_{3}$ nanoparticles were examined by scanning electron microscopy (SEM), X-Ray diffraction (XRD) pattern was recorded with pananalytical X-ray diffractometer using $\mathrm{CuK} \alpha$ radiation $(\lambda=1.5406 \AA$ Á). The IR spectra of chromium oxide synthesized from three different methods are shown in Figures 1(a)-(c). It shows that the characteristic bands are at $967 \mathrm{~cm}^{-1}-1037$ $\mathrm{cm}^{-1}, 585 \mathrm{~cm}^{-1}-641 \mathrm{~cm}^{-1}$ and $1046 \mathrm{~cm}^{-1}-1085 \mathrm{~cm}^{-1}$. Bands at $967 \mathrm{~cm}^{-1}-1037 \mathrm{~cm}^{-1}$ are assigned to $\mathrm{Cr}=\mathrm{O}$ vibrations, $585 \mathrm{~cm}^{-1}-641 \mathrm{~cm}^{-1}$ are assigned to $\mathrm{Cr}-\mathrm{O}$ vibrations and $1046 \mathrm{~cm}^{-1}-1085 \mathrm{~cm}^{-1}$ are relatively assigned to $\mathrm{Cr}-\mathrm{O}-\mathrm{Cr}$ vibrations.

The X-ray diffraction pattern obtained for the chromium oxide nanoparticles from three different methods are as shown in Figures 2(a)-(c). The XRD spectrum contains peaks that are clearly distinguishable. All of them can be perfectly indexed to crystalline $\mathrm{Cr}_{2} \mathrm{O}_{3}$ not only in peak position, but also in their relative intensity. The peaks with $2 \theta$ values of $24.6^{\circ}, 36.3^{\circ}, 50.2^{\circ}$ and $63.62^{\circ}$ correspond to the crystal planes of (012), (110), (024) and (214) of crystalline $\mathrm{Cr}_{2} \mathrm{O}_{3}$, respectively. An average crystalline size, $D_{\mathrm{hkl}}$ was estimated using the Debye-Scherrer equation given below for all X-ray diffraction peaks.

$$
D_{\mathrm{hk} 1}(\mathrm{~A} 0)=\frac{K \lambda}{\beta \cos \theta}
$$

Where $\mathrm{K}$ is a shape factor which normally ranges between 0.9 and 1.0 (in our case $\mathrm{K}=0.9$ ), $\lambda$ is the $\mathrm{X}$-ray wavelength, and $\beta$ and $\theta$ are the half width of the peak and half of the Bragg angle, respectively. Using the equation, the crystalline sizes of $\mathrm{Cr}_{2} \mathrm{O}_{3}$ nanoparticles which were synthesized from method (1), electrochemical method (2) and method (3) were found to be $65 \mathrm{~nm}, 79$ $\mathrm{nm}$ and $41 \mathrm{~nm}$ respectively.
The UV-Visible spectrum of $\mathrm{Cr}_{2} \mathrm{O}_{3}$ is shown in Figure 3 which shows maximum absorption at $430 \mathrm{~nm}$ which is a characteristic value for $\mathrm{Cr}_{2} \mathrm{O}_{3}$ as reported in the literature [22].

The morphological studies of synthesized $\mathrm{Cr}_{2} \mathrm{O}_{3}$ nanoparticles analyzed by scanning electron microscopy are shown in Figures 4(a)-(c). Compared to three different methods the nanoparticles were well separated and no agglomeration was observed in method (3).

\subsection{Chromium Oxide as a Catalyst in the Course of $\mathrm{KMnO}_{4}$ Decomposition}

It was elucidated that the more p-type character the solid catalyst have, the more pronounced is the effect on the reaction rate. Trying to compare the influence of chromium oxide catalyst as a p-type semiconductor in the course of other decomposition reaction will have great value in view of the practical importance for oxygen evolution. It has been suggested that its decomposition process includes an electron transfer from one permanganate ion to another with formation of stable $\mathrm{MnO}_{4}^{2-}$ ions and unstable $\mathrm{MnO}_{4}$ radicals [23]. Dowden [24] stated that the most active oxide catalyst for oxygen abstraction is solid oxides with vacancies in the d-orbital's. It is found that $\mathrm{MnO}_{2}$ enhances the rate of decomposition. Markowitz and Boryta [25] suggested that the effect of metal oxide on the decomposition can be attributed to the abstraction of atomic oxygen. On the other hand, Freeman and Coworkers [26] considered it to be due to a charge transfer mechanism. Therefore, the reaction can be represented for p-type catalyst as

$$
\begin{aligned}
& 2 \oplus \text { oxide }+2 \mathrm{MnO}_{4}^{-} \rightarrow 2 \mathrm{O}_{\text {oxide }}+\mathrm{MnO}_{4}+\mathrm{MnO}_{2} \\
& \rightarrow \mathrm{O}_{2}+\mathrm{MnO}_{4}^{2-}+\mathrm{MnO}_{2}+2 \oplus \text { oxide }
\end{aligned}
$$

Where $\oplus$ is a positive hole in the oxide, $\mathrm{O}_{\text {oxide }}$ is an oxygen atom abstracted by the oxide and $\mathrm{MnO}_{4}$ is a radical. In this work an investigation has been carried out to shed light on the reaction kinetics by which chromium oxide can act as a catalyst for the decomposition of $\mathrm{KMnO}_{4}$.

\section{Effect of $\mathrm{KMnO}_{4}$ on the rate}

The reaction was performed in the presence of $10 \mathrm{ml}$ of $\mathrm{KMnO}_{4}(0.0001 \mathrm{M}, 0.00005 \mathrm{M}$, and $0.0002 \mathrm{M})$ taken in three separate beakers consisting of $20.0 \mathrm{mg}$ of $\mathrm{Cr}_{2} \mathrm{O}_{3}$ nanoparticles which were synthesized from three different methods, namely method 1 , method 2 and method 3 . The experiment was carried out at room temperature and the rate of reaction was followed with respect to the change in concentration of $\mathrm{KMnO}_{4}$ by using a spectrophotometer. A plot of $\log \% \mathrm{~T}$ verses time was recorded where the rate of decomposition of $\mathrm{KMnO}_{4}$ increases in the order of method $3>\operatorname{method} 2>\operatorname{method} 1$, which is shown in Table 1 and Figures 5(a)-(c). The results show 


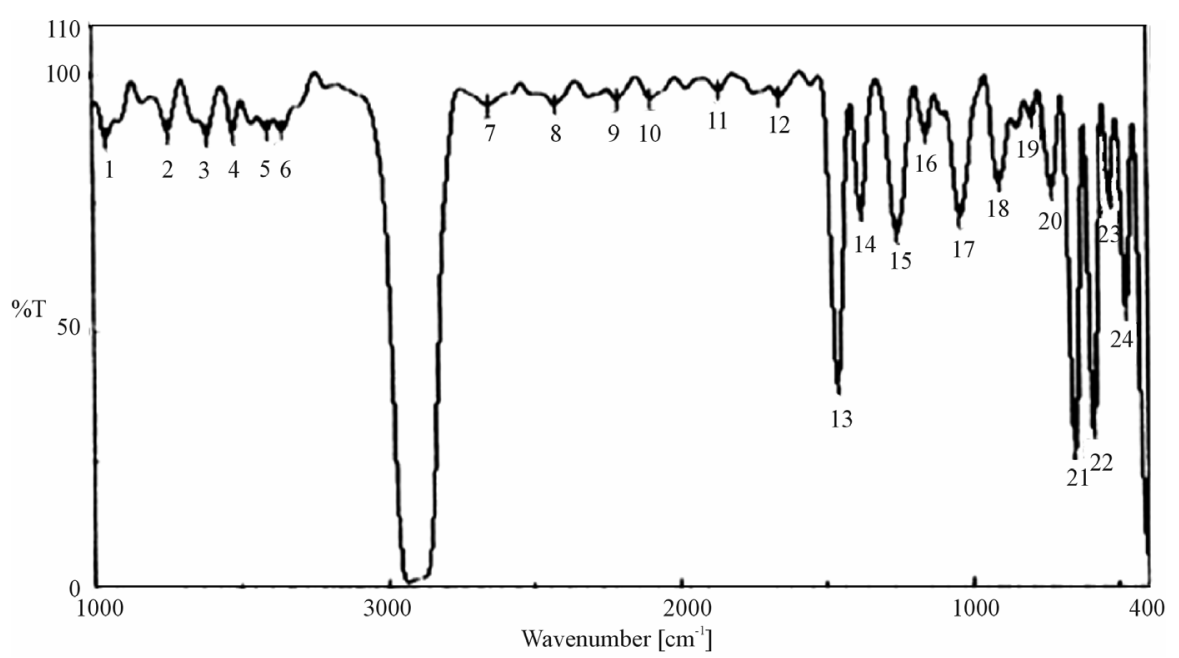

(a)

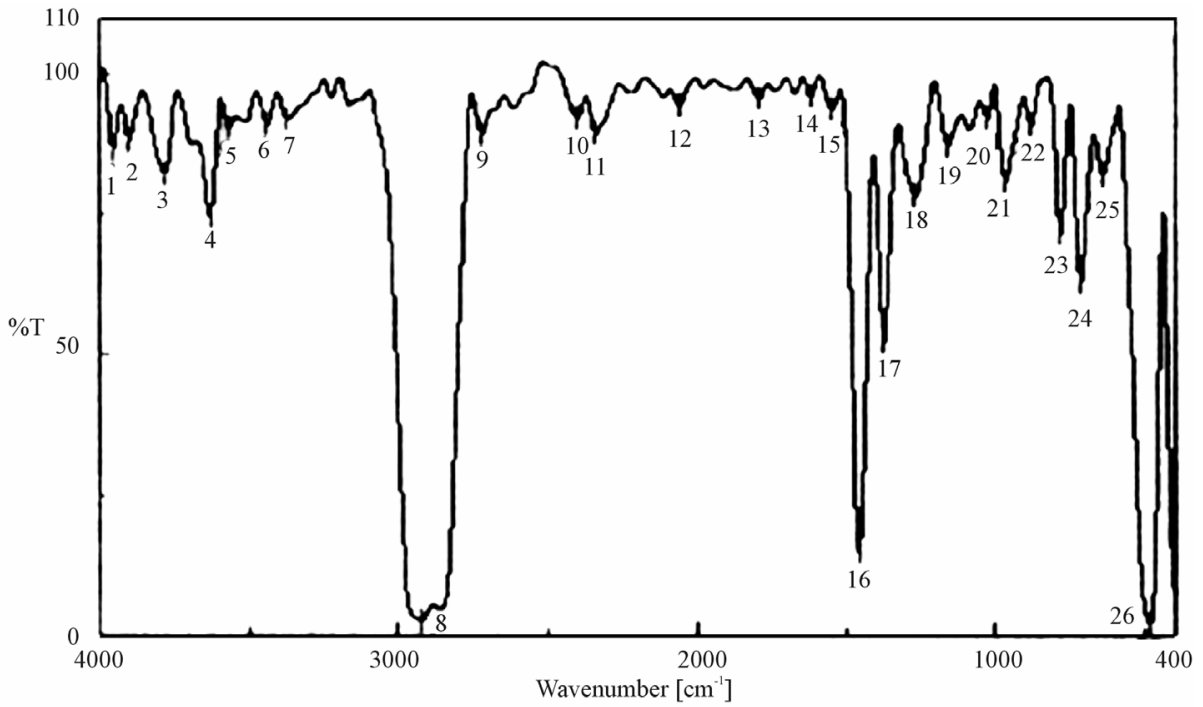

(b)

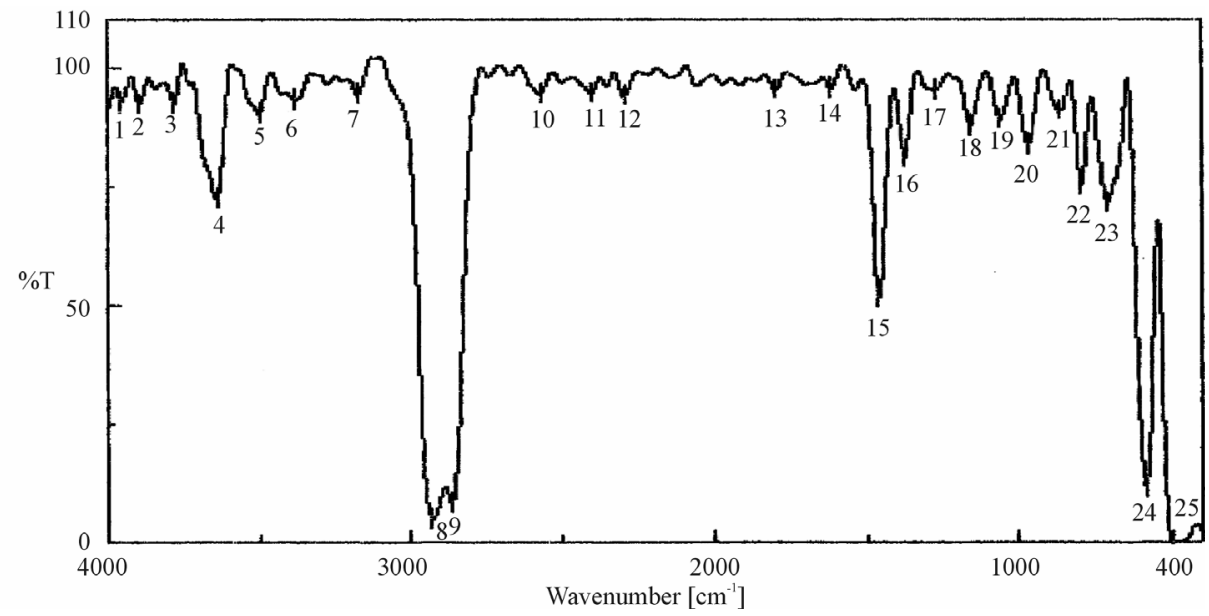

(c)

Figure 1. (a) IR spectra of $\mathrm{Cr}_{2} \mathrm{O}_{3}$ nanoparticles synthesised using method (1); (b) IR spectra of $\mathrm{Cr}_{2} \mathrm{O}_{3}$ nanoparticles synthesised by electrochemical method (2) using $\mathrm{K}_{2} \mathrm{Cr}_{2} \mathrm{O}_{7}$ and $\mathrm{H}_{2} \mathrm{SO}_{4}$ as medium; (c) IR spectra of $\mathrm{Cr}_{2} \mathrm{O}_{3}$ nanoparticles synthesised by electrochemical method (3) using $\mathrm{Pt} / \mathrm{Cr}$ electrode and $\mathrm{NaHCO}_{3}$. 


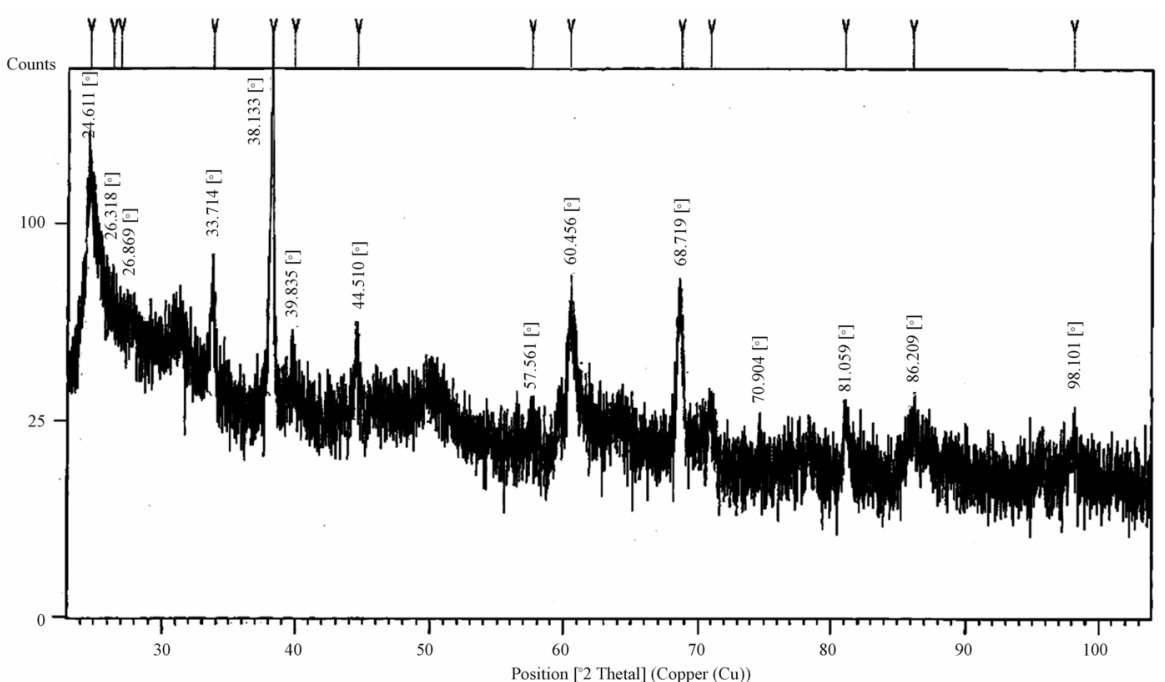

(a)

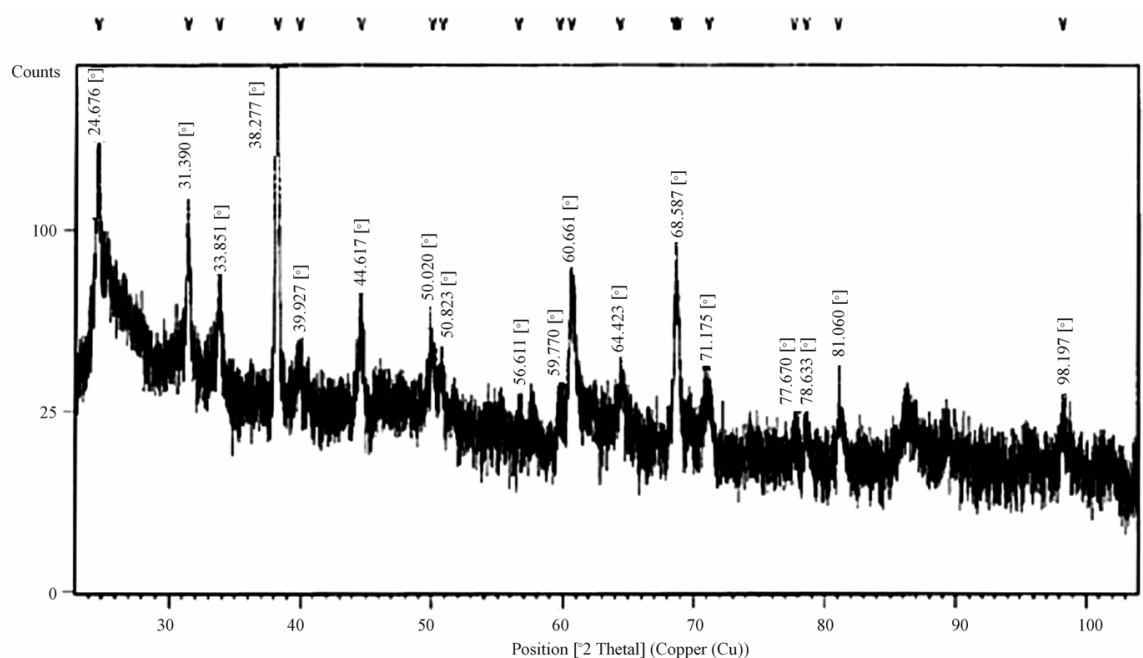

(b)

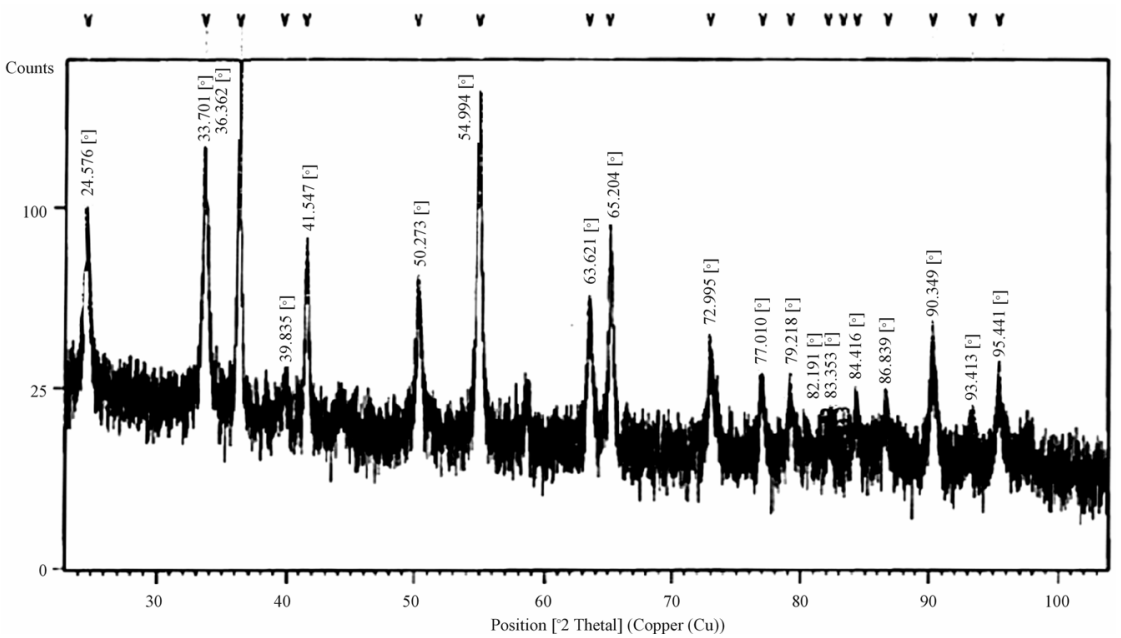

(c)

Figure 2. (a) XRD diffractogram of $\mathrm{Cr}_{2} \mathrm{O}_{3}$ nanoparticles synthesized using method (1); (b) XRD diffractogram of $\mathrm{Cr}_{2} \mathrm{O}_{3}$ nanoparticles synthesized by electrochemical method (2) using $\mathrm{K}_{2} \mathrm{Cr}_{2} \mathrm{O}_{7}$ and $\mathrm{H}_{2} \mathrm{SO}_{4}$ as medium; (c) XRD diffractogram of $\mathrm{Cr}_{2} \mathrm{O}_{3}$ nanoparticles synthesized by electrochemical method (3) using $\mathrm{Pt} / \mathrm{Cr}$ electrode and $\mathrm{NaHCO}_{3}$. 


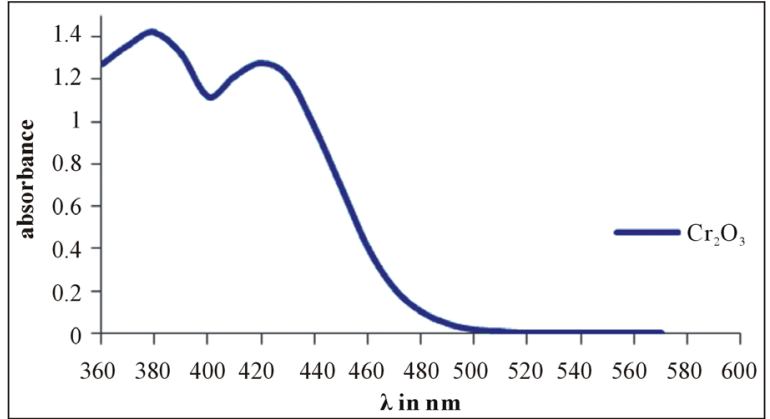

Figure 3. UV-Vis absorption spectrum of $\mathrm{Cr}_{2} \mathrm{O}_{3}$ nanoparticles in aqueous solution.

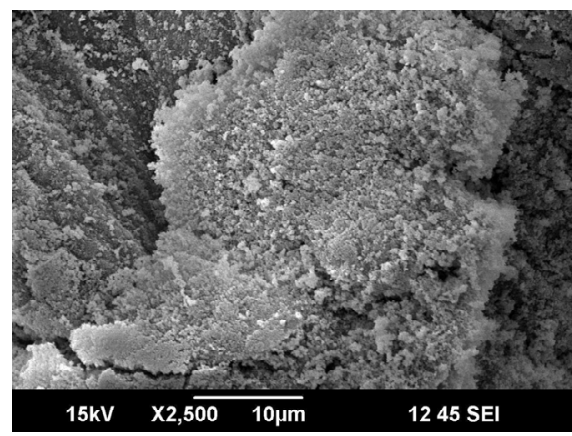

(a)

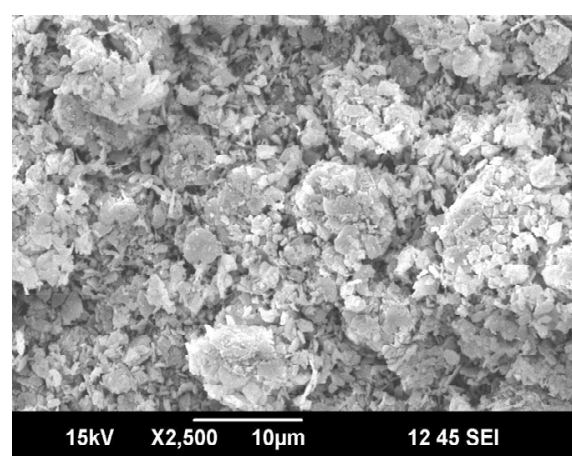

(b)

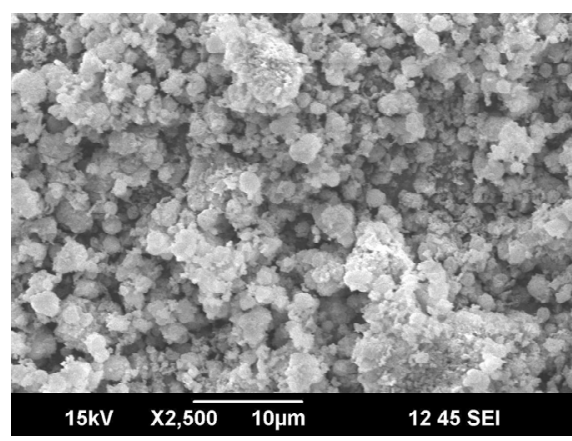

(c)

Figure 4. (a) SEM micrographs of $\mathrm{Cr}_{2} \mathrm{O}_{3}$ nanoparticles synthesized using method (1); (b) SEM micrographs of $\mathrm{Cr}_{2} \mathrm{O}_{3}$ nanoparticles synthesized by electrochemical method (2) using $\mathrm{K}_{2} \mathrm{Cr}_{2} \mathrm{O}_{7}$ and $\mathrm{H}_{2} \mathrm{SO}_{4}$ as medium; (c) SEM micrographs of $\mathrm{Cr}_{2} \mathrm{O}_{3}$ nanoparticles synthesized by electrochemical method (3) using $\mathrm{Pt} / \mathrm{Cr}$ and $\mathrm{NaHCO}_{3}$.

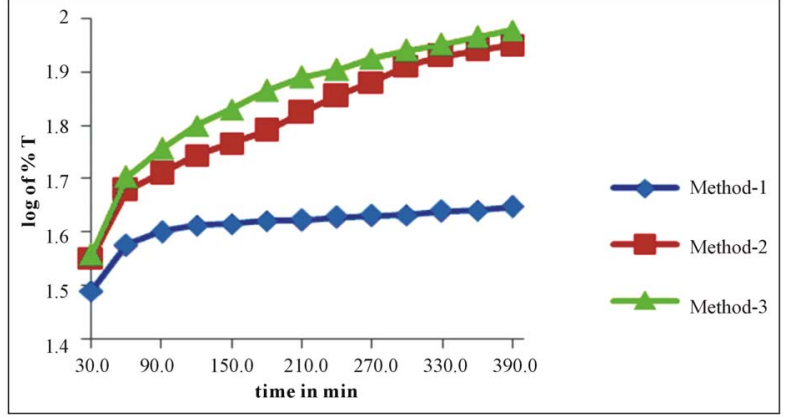

(a)

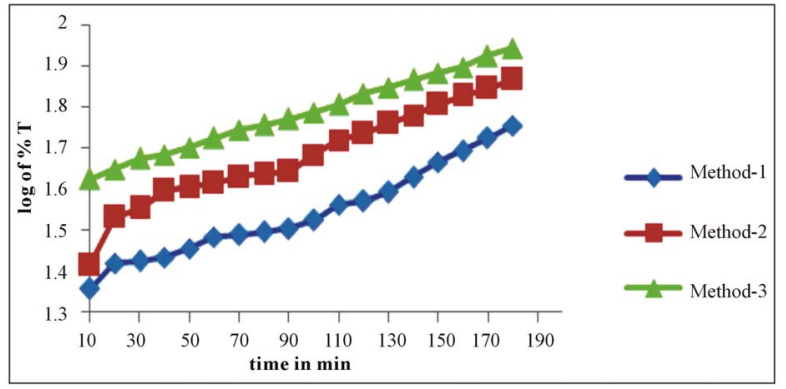

(b)

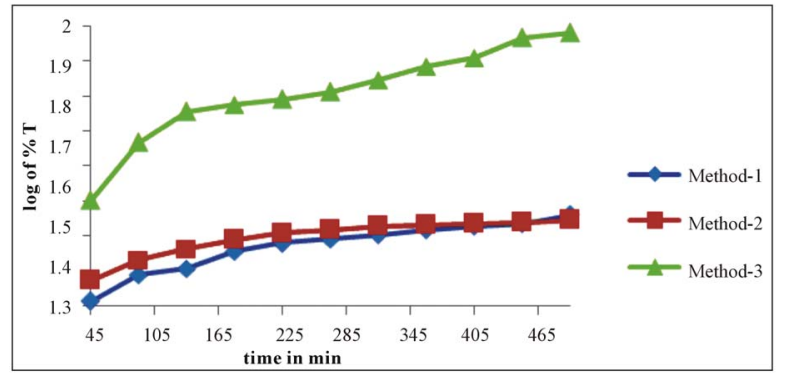

(c)

Figure 5. (a) Effect of $\mathrm{KMnO}_{4}(0.0001 \mathrm{M})$ on the rate of its decomposition; (b) Effect of $\mathrm{KMnO} 4(0.00005 \mathrm{M})$ on the rate of its decomposition; (c) Effect of $\mathrm{KMnO}_{4}(0.0002 \mathrm{M})$ on the rate of its decomposition.

Table 1. Effect of $\mathrm{KMnO}_{4}$ concentration on its rate of decomposition.

\begin{tabular}{cccc}
\hline \multirow{2}{*}[\mathrm{KMnO}_{4}]{} & \multicolumn{3}{c}{ rate constant k $\times 10^{-5} \mathrm{~s}^{-1}$} \\
\cline { 2 - 4 } & Method 1 & Method 2 & Method 3 \\
\hline $5.00 \times 10^{-5} \mathrm{M}$ & 6.90 & 8.06 & 8.44 \\
$1.00 \times 10^{-4} \mathrm{M}$ & 1.15 & 3.83 & 4.22 \\
$2.00 \times 10^{-4} \mathrm{M}$ & 1.05 & 1.91 & 3.45 \\
\hline
\end{tabular}

that the catalytic activity was very high for the $\mathrm{Cr}_{2} \mathrm{O}_{3}$ nanoparticles synthesized by method 3 , in which the size of $\mathrm{Cr}_{2} \mathrm{O}_{3}$ is $41 \mathrm{~nm}$, indicating smaller the size of $\mathrm{Cr}_{2} \mathrm{O}_{3}$ higher will be the catalytic activity.

Effect of $\mathrm{Cr}_{2} \mathrm{O}_{3}$ on the rate

The reaction was studied with varying amounts of 
$\mathrm{Cr}_{2} \mathrm{O}_{3}$ nanoparticles (10.0 mg, $20.0 \mathrm{mg}$ and $30.0 \mathrm{mg}$ ), keeping the concentration of $\mathrm{KMnO}_{4}\left(1.00 \times 10^{-4} \mathrm{M}\right)$ constant. The rate increases with increase in the amount of $\mathrm{Cr}_{2} \mathrm{O}_{3}$ nanoparticles, which is shown in Table 2 and Figures 6(a) and (b). The catalytic activity was observed greater for $\mathrm{Cr}_{2} \mathrm{O}_{3}$ synthesized by method 3 as its size is lower than the other two methods.

\subsection{Antibacterial Assay}

The $\mathrm{Cr}_{2} \mathrm{O}_{3}$ nanoparticles synthesized by the three different methods were tested for antibacterial activity by Disc diffusion method against Escherichia Coli and Pseudomonas aregunosa. The pure bacterial culture was subcultured on nutrient agar media. The activity was compared against standard Gentamycin. The concentration of nanoparticles was $50 \mathrm{mg} / \mathrm{ml}$ and $50 \mu \mathrm{l}$ of each solution was

Table 2. Effect of $\mathrm{Cr}_{2} \mathrm{O}_{3}$ nanoparticles on the rate of $\mathrm{KMnO}_{4}$ decomposition.

\begin{tabular}{cccc}
\hline \multirow{2}{*}{$\begin{array}{c}\text { Amount of } \\
\mathrm{Cr}_{2} \mathrm{O}_{3}(\mathrm{mg})\end{array}$} & \multicolumn{3}{c}{ rate constant $\mathrm{k} \times 10^{-5} \mathrm{~s}^{-1}$} \\
\cline { 2 - 4 } & 0.38 & Method 2 & Method 3 \\
\hline 10.0 & 1.15 & 0.78 & 2.30 \\
20.0 & 9.59 & 3.83 & 4.22 \\
30.0 & & 27.6 & 28.7 \\
\hline
\end{tabular}

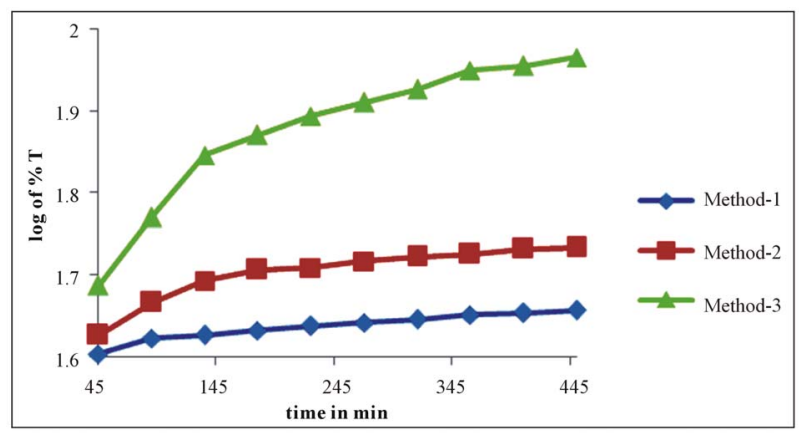

(a)

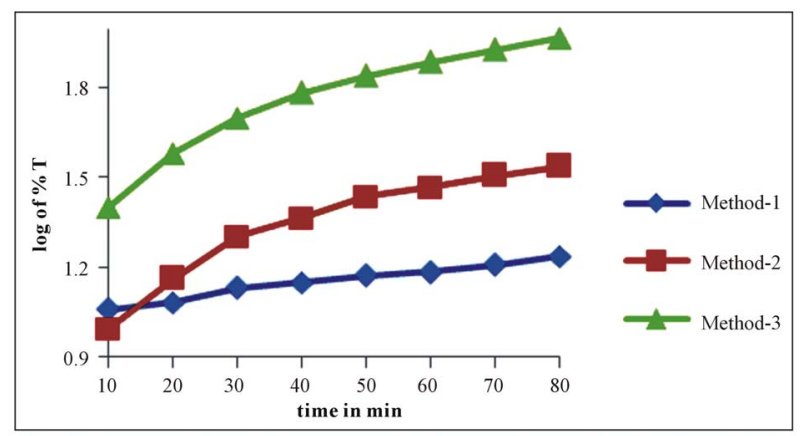

(b)

Figure 6. (a) Effect of $\mathrm{Cr}_{2} \mathrm{O}_{3}(10.0 \mathrm{mg})$ on the rate of its decomposition; (b) Effect of $\mathrm{Cr}_{2} \mathrm{O}_{3}(30.0 \mathrm{mg})$ on the rate of its decomposition. placed on a disc. After incubation for $48 \mathrm{hrs}$ at $37^{\circ} \mathrm{C}$, the different levels of zone inhibition of bacteria were measured. The zone inhibition in $\mathrm{mm}$ around $\mathrm{Cr}_{2} \mathrm{O}_{3}$ nanoparticles is shown in Table 3 and Figures 7(a) and (b).

The values from the table indicate that the nano particles of $\mathrm{Cr}_{2} \mathrm{O}_{3}$ synthesized from all the three methods show inhibiting effect towards different bacteria. However, the nano $\mathrm{Cr}_{2} \mathrm{O}_{3}(41 \mathrm{~nm})$ synthesized from method 3 shows a very good inhibiting effect close to the standard. The figure shows the zone inhibition of bacterial growth on agar plates. Hence, the results clearly demonstrate that the newly synthesized $\mathrm{Cr}_{2} \mathrm{O}_{3}$ nanoparticles were promising antimicrobial agents against bacteria.

\section{Conclusion}

Chromium(III) oxide nanoparticles synthesized by biological and electrochemical methods were characterized by UV-Visible, IR, SEM and XRD. The nanoparticles synthesized by $\mathrm{Pt} / \mathrm{Cr}$ and $\mathrm{NaHCO}_{3}$ and by electrochemical method act as very good catalysts for $\mathrm{KMnO}_{4}$ decomposition and as promising antibacterial agents.

Table 3. Zone of inhibition (mm) of $\mathrm{Cr}_{2} \mathrm{O}_{3}$ nanoparticles.

\begin{tabular}{ccccc}
\hline $\begin{array}{c}\text { Test } \\
\text { Organism }\end{array}$ & $\begin{array}{c}\mathrm{Cr}_{2} \mathrm{O}_{3}(\mathrm{M} \mathrm{1}) \\
(\mathrm{mm})\end{array}$ & $\begin{array}{c}\mathrm{Cr}_{2} \mathrm{O}_{3}(\mathrm{M} 2) \\
(\mathrm{mm})\end{array}$ & $\begin{array}{c}\mathrm{Cr}_{2} \mathrm{O}_{3}(\mathrm{M} 3) \\
(\mathrm{mm})\end{array}$ & $\begin{array}{c}\text { Standard/+ }{ }^{\mathrm{ve}} \\
\text { control (mm) }\end{array}$ \\
\hline $\begin{array}{c}\text { Escherichia } \\
\text { coli }\end{array}$ & 0.5 & 0.6 & 0.7 & 1.0 \\
$\begin{array}{c}\text { Pseudomonas } \\
\text { aregunosa }\end{array}$ & 0.4 & 0.5 & 0.6 & 0.9 \\
\hline
\end{tabular}

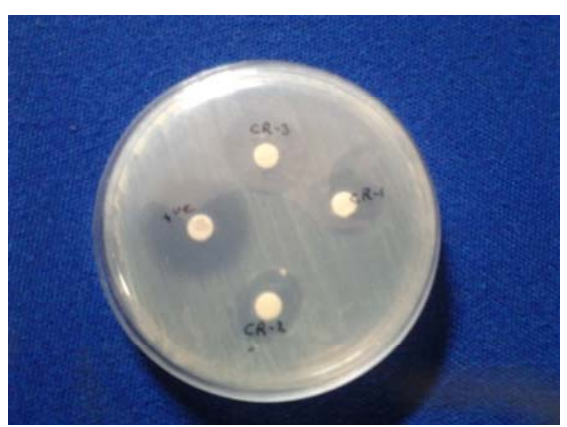

(a)

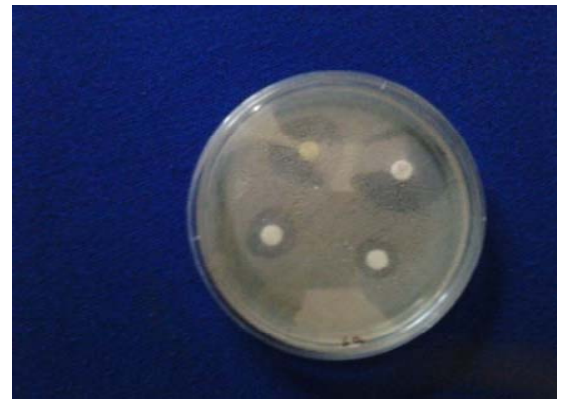

(b)

Figure 7. (a) Escherichia coli; (b) Pseudomonas aregunosa. 


\section{Acknowledgements}

One of the authors, Rakesh, acknowledges The University of Mysore and Jubilant Life Sciences Limited, Nanjangud, Mysore, for the grant of permission.

\section{REFERENCES}

[1] M. Bañobre-López, C. Vázquez-Vázquez, J. Rivas and M. A. López-Quintela, "Magnetic Properties of Chromium(III) Oxide Nanoparticles," Nanotechnology, Vol. 14, No. 2, 2003, pp. 318-322.

[2] M. Fernandez-Garcia, A. Martinez-Arias, J. C. Hanson and J. A. Rodriguez, "Nanostructured Oxides in Chemistry Characterization and Properties," Chemical Reviews, Vol. 104, No. 9, 2004, pp. 4063-4104. http://dx.doi.org/10.1021/cr030032f

[3] T. Tsoncheva, J. Rooggenbuck, D. Paneva, M. Dimitrov, I. Mitov and M. Fröbab, "Nanosized Iron and Chromium Oxides Supported on Mesoporous $\mathrm{CeO}_{2}$ and SBA-15 Silica Physicochemical and Catalytic Study," Applied Surface Science, Vol. 257, No. 2, 2010, pp. 523-530. http://dx.doi.org/10.1016/j.apsusc.2010.07.027

[4] T. V. M. Rao, Y. Yang and A. Sayari, "Ethane Dehydrogenation over Pore-Expanded Mesoporous Silica Supported Chromium Oxide Catalysts Preparation and Characterization," Journal of Molecular Catalysis A: Chemical, Vol. 301, No. 1-2, 2009, pp. 152-158. http://dx.doi.org/10.1016/j.molcata.2008.12.026

[5] X. Pang, K. Gao, F. Luo, Y. Emirov, A. A. Levin and A. A. Volinsky, "Investigation of Micro Structure and Mechanical Properties of Multi-Layer $\mathrm{Cr} / \mathrm{Cr}_{2} \mathrm{O}_{3}$ Coatings," Thin Solid Films, Vol. 517, No. 6, 2009, pp. 1922-1927. http://dx.doi.org/10.1016/j.tsf.2008.10.026

[6] X. Hou and K. L. Choy, "Synthesis of $\mathrm{Cr}_{2} \mathrm{O}_{3}$-Based Nanocomposite Coating within Corporation of Inorganic Fullerene-Like Nanoparticles," Thin Solid Films, Vol. 516, No. 23, 2008, pp. 8620-8624. http://dx.doi.org/10.1016/j.tsf.2008.06.045

[7] D.-W. Kim, S.-I. Shin, J.-D. Lee and S.-G. Oh, "Preparation of Chromia Nanoparticles by Precipitation-Gelation Reaction," Materials Letters, Vol. 58, No. 12-13, 2004, pp. 1894-1898. http://dx.doi.org/10.1016/j.matlet.2003.11.023

[8] P. Li, H. B. Xu, Y. Zhang, Z. H. Li, S. L. Zheng and Y. L. Bai, "The Effects of $\mathrm{Al}$ and $\mathrm{Ba}$ on the Colour Performance of Chromic Oxide Green Pigment," Dyes and Pigments, Vol. 80, No. 3, 2009, pp. 287-291. http://dx.doi.org/10.1016/j.dyepig.2008.07.016

[9] V. Teixeira, E. Sousa, M. F. Costa, C. Nunes, L. Rosa, M. J. Carvalho, M. Collares-Pereira, E. Roman and J. Gago, "Spectrally Selective Composite Coatings of $\mathrm{Cr}-\mathrm{Cr}_{2} \mathrm{O}_{3}$ and $\mathrm{Mo}-\mathrm{Al}_{2} \mathrm{O}$ for Solar Energy Aoolications," Thin Solid Films, Vol. 392, No. 2, 2001, pp. 320-326. http://dx.doi.org/10.1016/S0040-6090(01)01051-3

[10] Z. Pei, H. Xu and Y. Zhang, "Preparation of $\mathrm{Cr}_{2} \mathrm{O}_{3}$ Nanoparticles via $\mathrm{C}_{2} \mathrm{H}_{5} \mathrm{OH}$ Hydrothermal Reduction," Journal of Alloys and Compounds, Vol. 468, No. 1-2, 2008, pp. L5-L8. http://dx.doi.org/10.1016/j.jallcom.2007.12.086
[11] S. El-sheikh, M. Mohamed and O. A. Fouad, "Synthesis and Structure Screening of Nanostructured Chromium Oxide Powders," Journal of Alloys and Compounds, Vol. 482, No. 1-2, 2009, pp. 302-307. http://dx.doi.org/10.1016/j.jallcom.2009.04.011

[12] X.-Z. Fu, X.-X. Luo, J.-L. Luo, K. T. Chuang, A. R. Sanger and A. Krzywicki "Ethane Dehydrogenation over Nano- $\mathrm{Cr}_{2} \mathrm{O}_{3}$ Anode Catalyst in Proton Ceramic Fuel Cell Reactors to Co-Produce Ethylene and Electricity," Journal of Power Sources, Vol. 196, No. 3, 2011, pp. 10361041. http://dx.doi.org/10.1016/j.jpowsour.2010.08.043

[13] D.-W. Kim and S.-G. Oh, "Agglomeration Behavior of Chromia Nanoparticles Prepared by Amorphous Complex Method Using Chelating Effect of Citric Acid," Materials Letters, Vol. 59, No. 8-9, 2005, pp. 976-980. http://dx.doi.org/10.1016/j.matlet.2004.09.053

[14] L. Li, Z. Yan, G. Q. Lu and Z. H. Zhu, "Synthesis and Structure Characterization of Chromium Oxide Prepared by Solid Thermal Decomposition Reaction," The Journal of Physical Chemistry B, Vol. 110, No. 1, 2006, pp. 178183. http://dx.doi.org/10.1021/jp053810b

[15] M. Abecassis-Wolfovich, H. Rotter, M. V. Landau, E. Korin, A. I. Erenburg, D. Mogilyansky and E. Gartstein, "Texture and Nanostructure of Chromia Aergels Prepared by Urea-Assisted Homogeneous Precipitation and Low Temperature Supercritical Drying," Journal of Non-Crystalline Solids, Vol. 318, No. 1-2, 2003, pp. 95-111. http://dx.doi.org/10.1016/S0022-3093(02)01881-1

[16] U. Balchandran, R. W. Siegel, Y. X. Liao and T. R. Askew, "Synthesis, Sintering and Magnetic Properties of Nanophase $\mathrm{Cr}_{2} \mathrm{O}_{3}$," Nanostructure. Mater, Vol. 5, No. 5, 1995, pp. 505-512. http://dx.doi.org/10.1016/0965-9773(95)00266-H

[17] D. Vollath, D. V. Szabo and J. O. Willis, "Magnetic Properties of Nanocrystalline $\mathrm{Cr}_{2} \mathrm{O}_{3}$ Synthesised in Microwave Plasma," Materials Letters, Vol. 29, No. 4-6, 1996, pp. 271-279. http://dx.doi.org/10.1016/S0167-577X(96)00158-9

[18] Y. Wang, X. Yuan, X. Liu, X. Liu, J. Ren, W. Tong, Y. Wang and G. Lu, "Mesoporous Single-Crystal $\mathrm{Cr}_{2} \mathrm{O}_{3}$ : Synthesis, Characterization, and Its Activity in Toluene Removal, Solid State," Sciences, Vol. 10, No. 9, 2008, pp. 1117-1123.

[19] B. R. Srilatha and S. Ananda, "In Vitro Antioxidant and Free Radical Scavenging Activities of Mukia Maderaspatana (Linn)," Journal of Pharmacy Research, Vol. 5, No. 6, 2012, pp. 3296-3303.

[20] G. Chaitanya Lakshmi, S. Ananda, R. Somashekar and C. Ranganathaiah, "Synthesis of $\mathrm{ZnO} / \mathrm{ZrO}_{2}$ Nano Composites by Electrochemical Method and Its Application for Photocatalytic Degradation of Fast Green FCF Dye and Paper Dyeing and Printing Press Effluents," International Journal of Advanced Materials Science, Vol. 3, No. 6, 2012, pp. 221-237.

[21] G. H. Annal Therese and P. Vishnu Kamath, "Electrochemical Synthesis of Metal Oxides and Hydroxides," Chemistry of Materials, Vol. 12, No. 5, 2000, pp. 11951204. http://dx.doi.org/10.1021/cm990447a

[22] C. Ramesh, K. Mohan Kumar, M. Senthil and V. Ra- 
gunathan, "Antibacterial Activity of $\mathrm{Cr}_{2} \mathrm{O}_{3}$ Nanoparticles Against E. coli; Reduction of Chromate Ions by Arachis Hypogaea Leaves," Archives of Applied Science Research, Vol. 4, No. 4, 2012, pp. 1894-1900.

[23] V. V. Boldyev, "Mechanism of Thermal Decomposition of Potassium Permanganate in the Solid Phase," Journal of Physics and Chemistry of Solids, Vol. 30, No. 5, 1968, pp. 1215-1223. http://dx.doi.org/10.1016/0022-3697(69)90379-5

[24] W. E. Garna, "Proceedings of a Symposium on Chemisorption," Academic Press, New York, 1957, p. 5.
[25] M. M. Markowitz and D. A. Boryta, "The Differential Thermal Analysis of Perchlorates. VII. Catalytic Decompositions of the Alkali Metal Perchlorates by Manganese Dioxide," The Journal of Physical Chemistry, Vol. 69, No. 4, 1969, pp. 1114-1123.

http://dx.doi.org/10.1021/j100888a005

[26] E. S. Freeman and D. A. Anderson, "Effects of Radiation and Doping on the Catalytic Activity of Magnesium Oxide on the Thermal Decomposition of Potassium Perchlorate," Nature, Vol. 206, No. 4982, 1976, pp. 378-379. http://dx.doi.org/10.1038/206378a0 